\title{
Kompetensi Pedagogik Guru PAUD dalam Perencanaan dan Pelaksanaan Pembelajaran
}

\author{
Theresia Alviani Sum ${ }^{\varpi_{1}}$, Emilia Graciela Mega Taran² \\ Pendidikan Guru Pendidikan Anak Usia Dini, Universitas Katolik Indonesia Santu Paulus \\ Ruteng \\ DOI: $\underline{10.31004 / o b s e s i . v 4 i 2.287}$
}

\begin{abstract}
Abstrak
Penelitian ini bertujuan untuk mengetahui kompetensi pedagogik yang dimiliki oleh guru PAUD yang berdampak pada kemampuan penyusunan dan pelaksanaan pembelajaran di PAUD pada beberapa lembaga di Kabupaten Manggarai. Jenis penelitian yang digunakan adalah deskriptif kualitatif yang bertujuan mendeskripsikan kompetensi pedagogik guru PAUD pada 20 lembaga PAUD di Kabupaten Manggarai. Obyek penelitian adalah para guru dan kepala sekolah PAUD dengan menggunakan instrument penelitian wawancara, observasi dan dokumentasi. Hasil penelitian menunjukan pertama, kualifikasi akademik seorang guru PAUD mempengaruhi kemampuan, pengetahuan serta pemahaman guru terhadap peserta didik. Kedua, masih banyak lembaga PAUD yang kurang memiliki kemampuan dalam menyusun perencanaan pembelajaran yang menyenangkan serta pemahaman akan pentingnya penyusunan perencanaan pembelajaran masih minim. Ketiga, minimnya kompetensi pedagogik yang dimiliki akhirnya mempengaruhi proses pembelajaran yang berkualitas bagi anak, pembelajaran menjadi tidak menyenangkan serta penilaian pembelajaran yang dilakukan guru belum dapat menggambarkan perkembangan yang mencakup segala aspek perkembangan anak.
\end{abstract}

Kata kunci: kompetensi pedagogik; guru PAUD; perencanaan pembelajaran.

\begin{abstract}
This study aims to determine the pedagogical competencies of PAUD teachers that have an impact on the ability to formulate and implement learning in PAUD at several institutions in Manggarai Regency. This type of research is descriptive qualitative that aims to describe the pedagogical competence of PAUD teachers in 20 PAUD institutions in Manggarai Regency. The object of research is the teachers and PAUD principals using interview, observation and documentation research instruments. The results showed first, the academic qualifications of a PAUD teacher affect the ability, knowledge and understanding of teachers to students. Secondly, there are still many PAUD institutions that lack the ability to arrange fun learning plans and the understanding of the importance of learning planning is still minimal. Third, the lack of pedagogical competence that is owned ultimately affects the quality of the learning process for children, learning becomes unpleasant and the assessment of learning by the teacher has not been able to describe developments that cover all aspects of child development.
\end{abstract}

Keywords: teacher pedagogical competence; teacher of early childhood education; learning planning.

Copyright (c) 2020 Theresia Alviani Sum, Emilia Graciela Mega Taran

$\triangle$ Corresponding author :

Email Address : annysum85@gmail.com (Ruteng Flores, Indonesia)

Received 8 September 2019, Accepted 30 December 2019, Published 9 January 2020 


\section{PENDAHULUAN}

Pendidik merupakan suatu prioritas pertama dalam mewujudkan keberhasilanya suatu pendidikan, oleh karena itu melihat kemajuan zaman yang serba cepat dan canggih perlunya seorang pendidik meningkatkan kualitasnya sehingga dapat menjajarkan pengetahuan dengan tuntutan zaman sekarang ini. Setiap pendidik professional diharapkan harus mempunyai kompetensi dan penguasaan yang mendalam dalam bidangnya. Penguasaan pengetahuan inilah yang menjadi syarat penting di samping keterampilan keterampilan lainnya. Usman berpendapat dalam penelitian Habibullah guru merupakan jabatan atau profesi yang memerlukan keahlian atau kompetensi tertentu dalam rangka melaksanakan tugas dan fungsinya sebagai guru.(Habibullah, 2012) Tanpa memiliki keahlian, kemampuan atau kompetensi tertentu yang harus dimilikinya, guru tidak dapat menjalankan tugas dan fungsi profesinya sebagai guru.

Mengutip hasil riset yang disponsori Bank Dunia di 29 negara berkembang menunjukkan fungsi guru amat strategis dalam setiap upaya peningkatan mutu pendidikan. Guru menjadi pusat perhatian karena sangat besar peranannya dalam setiap usaha peningkatan mutu pendidikan. (Rifma, 2013) Guru merupakan titik sentral dalam usaha mereformasi pembelajaran dan mereka menjadi kunci keberhasilan setiap usaha peningkatan mutu pendidikan.

Hasil pembelajaran yang berkualitas akan berpengaruh pada prestasi belajar yang diperoleh siswa. Dalam mendorong semangat belajar siswa untuk meningkatkan prestasi belajar dan memahami economic literacy, guru harus bisa memahami karakter siswa, melakukan perancangan pembelajaran, melakukanevaluasi pembelajaran dan bahkan dituntut untuk bisamengaktualisasikan berbagai potensi yang dimiliki siswa. Kemampuan guru dalam mengelola aktivitas pembelajaran ini merupakan kompetensi pedagogic guru. Selain itu guru juga harus bisa menguasai materi pembelajaran secara meluas dan mendalam untuk membimbing siswa memenuhi standar kompetensi yang ditetapkan dalam Standar Nasional Pendidikan yang tercermin dalam kompetensi profesionalnya. Hal ini sesuai dengan hasil penelitian yang dilakukan oleh Haryono yang menyimpulkan bahwa terdapat pengaruh positif langsung antara kualitas proses pembelajaran terhadap economic literacy. (Wulandari, 2012)

Dari hasil penelitian yang dilakukan oleh Farwan, Ali dan Lukmanulhakim diperoleh data bahwa sebagian besar guru PAUD memiliki pemahaman yang sedang tentang kompetensi pedagogik yang harus dimiliki oleh guru PAUD. Hal ini menunjukan bahwa jika pemahaman guru rendah maka hal ini akan berimbas pada kualitas pembelajaran PAUD yang dilaksanakan guru di lembaga PAUD (Ronny Farwan, 2017).

Dari hasil penelitian de Gomes, Rahmat, dan Palmin membuktikan bahwa 99,51\% guru PAUD di Kabupaten Manggarai belum memenuhi standar kualifikasi akademik sebagaimana yang tertuang dalam Permendikbud No. tahun 2014. Sebagian besar dari mereka masih berijazah SMA atau sederajad dan ibu rumah tangga yang tidak pernah dibekali dengan sejumlah kompetensi guru PAUD.(Fransiskus De omes, Stephanus Turibius Rahmat, 2017) Hal ini kemudia berdampak pada kualitas proses pembelajaran di PAUD. Selain itu, diperoleh data: (1) kurikulum masih terkategori kurang baik yang tampak pada visi dan misi lembaga, Program Tahunan, Program Semeteran, Rencana Pelaksanaan Pembelajaran Mingguan, Rencana Pelaksanaan Pembelajaran Harian, instrumen penilaian perkembangan anak, dan pelaporan yang belum jelas; (2) proses pembelajaran atau stimulasi perkembangan anak tidak berbasis pada perencanaan yang jelas; dan (3) berbagai kegiatan penunjang penyelenggaraan PAUD seperti kemitraan, layanan administrasi, dan deteksi dini tumbuh kembang anak belum berjalan dengan baik

Dampak dari rendahnya kompetensi guru PAUD misalnya: dalam kompetensi professional, masih banyak guru PAUD yang memiliki jenjang pendidikan akhir SMA yang dipercayakan untuk menjadi guru PAUD.. Hal ini dilakukan karena ketiadaan tenaga pendidik dibidang PAUD. Hal lain adalah dibidang pedagogik, masih banyak guru PAUD 544 | Jurnal Obsesi : Jurnal Pendidikan Anak Usia Dini, 4(2), 2020 
yang belum bisa menyusun rencana pembelajaran. Hal ini terjadi entah para pendidik tidak tahu atau tidak kreatif dalam menyusun pembelajarannya sendiri. Banyak lembaga yang masih copy-paste dalam menggunakan rencana pembelajaran. Dengan didasari kenyataan diatas, maka peneliti merasa perlu menggali sejauh mana kompetensi yang dimiliki oleh para guru PAUD untuk menjadi bahan kajian bagi pemerintah dalam merumuskan kegiatan yang mungkin akan menjawabi persoalan terkait dengan kompetensi guru.

\section{METODOLOGI}

Sesuai dengan permasalahan penelitian yang telah diuraikan pada latar belakang, maka jenis penelitian ini merupakan penelitian deskriptif kualitatif. Peneliti akan melakukan studi dokumen, penyebaran angket dan observasi di lembaga PAUD di kecamatan Langke Rembong kabupaten Manggarai

Penelitian dilakukan di wilayah kecamatan Langke Rembong, kabupaten Manggarai, dengan subjek penelitiannya adalah para guru PAUD. Jumlah responden yang diteliti fleksibel tergantung pada pengembangan data/informasi yang diperoleh selama kegiatan penelitian berlangsung. Lembaga PAUD yang akan dijadikan sebagai tempat penelitian dibatasi pada beberapa lembaga PAUD yang paling dekat dengan peneliti karena mempertimbangkan waktu dan biaya yang akan dibutuhkan selama penelitian.

Hal yang akan digali dalam penelitian ini adalah kompetensi pedagogik yang dimiliki oleh para guru PAUD yang dapat mempengaruhi proses belajar anak di lembaga PAUD. Hal yang ingin diukur dari instrument angket adalah: kompetensi pendidik terkait social dan kepribadiannya serta konsep pedagogi, bagaimana menjadi seorang guru. Informasi ini akan didukung oleh hasil observasi dimana proses pembelajaran guru akan didokumentasikan untuk mendukung data penelitian. Data penelitian kemudia akan semakin didukung oleh adanya dokumentasi berupa foto dan dokumen rencana pembelajaran, dll

Analisis data yang digunakan adalah deskriptif analisis, yakni analisis yang memberikan gambaran mengenai hal-hal yang telah diteliti. Sedangkan metode yang digunakan dalam penelitian ini adalah metode analisis kualitatif.

Hasil temuan akan dikumpulkan dan dianalisis secara mendalam dan lebih lanjut akan dipaparkan secara deskriptif. Untuk membuat hasil penelitian lebih bersifat informatif, maka peneliti akan melengkapi laporan penelitian dengan grafik matriks dan bagan.

\section{HASIL DAN PEMBAHASAN}

Profesionalisme guru sangat terkait dengan kemampuan mewujudkan atau mengaktualisasikan kompetensi yang dipersyaratkan bagi setiap guru. Kompetensi diartikan sebagai pengetahuan, keterampilan, dan nilai-nilai dasar yang direfleksikan dalam kebiasaan berpikir dan bertindak. Arti lain dari kompetensi adalah spesifikasi dari pengetahuan, keterampilan, dan sikap yang dimiliki seseorang serta penerapannya di dalam pekerjaan, sesuai dengan stndar kinerja yang dibutuhkan oleh lapangan. Kompetensi yang dimiliki guru akan menunjukkan kualitas guru yang sebenarnya. Kompetensi tersebut akan terwujud dalam bentuk penguasaan pengetahuan, keterampilan maupun sikap profesional dalam menjalankan tugasnya. Oleh sebab itu Standar Kompetensi Guru dapat diartikan sebagai suatu pernyataan tentang kriteria yang dipersyaratkan, ditetapkan dan disepakati bersama dalam bentuk pengetahuan, keterampilan dan sikap bagi seorang tenaga kependidikan sehingga layak disebut kompeten. (Marienda, Zainuddin, \& Hidayat, 2015)

Penelitian dilaksanakan pada 28 lembaga PAUD yang ada di Kabupaten Manggarai. Ke-28 lembaga PAUD tersebut Antara lain: PAUD Santu Yosef, TKK Bunga Mawar Santa Elisabeth, PAUD Yesus Ekaristi Poka, TKK Dharma Wanita, TK Santu Nino, TK St Fransiskus Asisi Karot, TK Inviolata, TKK Arengkoe Pagal, TK Negeri Reo, TKK Negeri Golojambu Narang, TK Bunda Maria Cancar, PAUD Companglait, TKK Santu Gabriel Leda, 
TKK Negeri Pembina Golowelu, TKK Wejang Asi Mano, PAUD Santu Mikael Kole Kecamatan Satar Mese Utara, PAUD Santo Pio Langke Majok, TK Santu Fransiskus Xaverius, TK Negeri Paka Satar Mese, PAUD santa Anastasia Nderu Reo, TK Kemala Bhayangkari Ruteng, PAUD Mrie Louise, PAUD Santa Juliana, TK Negeri Cibal, PAUD Montemurro, PAUD Bunda Maria Gracia Nekang, PAUD Madre Addatis Dari Nocera, TKK santa Clara.

\section{Pemahaman wawasan dan Landasan kependidikan}

Guru harus memiliki pemahaman dan landasan kependidikan. Pemahaman wawasan dan landasan kependidikan yang dimiliki oleh guru memiliki latar belakang pendidikan yang baik atau sesuai dengan bidang, dengan memiliki latar belakang pendidikan keilmuan yang baik seorang guru akan paham tentang hakikat pendidikan dan konsep pendidikan. Musfah menjelaskan pemahaman yang benar tentang konsep pendidikan akan membuat guru sadar bagaimana harus bersikap di sekolah dan masyarakat, dan bagaimana cara memenuhi kualifikasi statusnya sebagai guru professional. (Jejen, 2012)

Dari hasil penelitian yang dilakukan melalui studi dokumen pada beberapa lembaga PAUD yang ada di Kabupaten Manggarai, masih banyak lembaga PAUD yang memiliki tenaga pendidik tidak berkualifikasi PAUD. Guru yang ada dilembaga tersebut hanya berkualifikasi sarjana kependidikan umum, bukan spesifikasi PAUD, berijasah SMA atau diploma jurusan lainnya.

Beberapa usaha yang dilakukan oleh para guru untuk mengembangkan kompetensi mereka di bidang PAUD adalah mengikuti pelatihan, seminar, lokakarya ataupun workshop baik didalam daerah ataupun di luar daerah. Dari hasil wawancara yang dilakukan, hampir semua guru PAUD di lembaga yang dijadikan tempat penelitian mengikuti kegiatankegiatan pengembangan diri sebagai pendidik PAUD.

\section{Pemahaman tentang peserta didik}

Pemahaman karakteristik siswa dilakukan dengan memahami keunggulan dan kekurangan siswa. Menurut Bahri, guru harus mengenal dan memahami siswa dengan baik, memahami tahap perkembangan yang telah dicapainya, kemampuannya, keunggulan dan kekurangannya, hambatan yang dihadapi serta faktor dominan yang mempengaruhinya. (Syaiful, 2005)

Mulyasa menegaskan dalam penelitian Nurhamidah bahwa motivasi dapat menyebabkan terjadinya suatu perubahan yang ada pada diri manusia, baik yang menyangkut kejiwaan, perasaan, maupun emosi, dan kemudian bertindak atau melakukan sesuatu untuk mencapai tujuan. Motivasi merupakan alah satu faktor yang dapat meningkatkan kualitas pembelajaran, karena peserta didik akan belajar dengan sungguhsungguh apabila memiliki motivasi yang tinggi.(Nurhamida, 2018) Oleh karena itu, untuk membangkitkan kualitas pembelajaran, guru harus mampu membangkitkan motivasi belajar peserta didik yang diharapkan dapat mencapai tujuan pembelajaran.

Dari hasil observasi yang dilakukan, masih ada lembaga yang gurunya belum mampu untuk memperlakukan anak sesuai dengan karakteristik anak. Hal ini dikarenakan jumlah guru yang terbatas yang berdampak pada pemberian jenis kegiatan kadangkala tidak sesuai dengan usia anak. Kegiatan main yang disedikan oleh guru tidak mampu untuk mengembangkan aspek perkembangan secara optimal. Guru hanya melakukan beberapa kegiatan yang sering dilakukan yaitu: mewarnai, menggunting dan menempel. Ketiga kegiatan ini seringkali dilakukan secara bergantian. 


\section{Kemampuan guru dalam perencanaan pembelajarn}

Adapun perencanaan pembelajaran yang dipersiapkan oleh guru meliputi pembuatan RPPH, pengelolaan kelas, mempersiapkan media yang dibutuhkan. Perencanaan adalah serentetan program kegiatan yang akan dikerjakan selama waktu tertentu untuk memenuhi target yang diharapkan. (Muhamad, 2012) Sedangkan pembelajaran adalah proses yang dilakukan untuk memperoleh suatu perubahan yang baru.(Majid, 2018) Kemampuan guru dalam merancang/ merencanakan RPPH sejalan dengan pendapat Wahyuni dan Ibrahim dalam penelitian Wahyuni dan Berliani yang mengungkapkan perencanaan memegang peranan penting dalam setiap kegiatan, termasuk dalam sebuah pembelajaran. Dalam kaitannya dengan pembelajaran, yang dimaksud dengan perencanaan pembelajaran adalah proses penyusunan berbagai keputusan pembelajaran yang akan dilaksanakan dalam proses kegiatan pembelajaran untuk mencapai kompetensi pelajaran yang akan dilaksanakan dalam proses kegiatan pembelajaran untuk mencapai kompetensi pembelajaran yang telah ditetapkan.(Wahyuni \& Berliani, 2018)

Kompetensi pedagogik guru PAUD di Kabupaten Manggarai dalam merencanakan kegiatan pembelajaran anak usia dini bisa dikatakan baik. Dimana guru telah mampu menerapkan serta menjabarkan tema kedalam sub tema yang lebih terperinci. Kompetensi pedagogik guru dalam merencanakan pembelajaran harus lebih ditingkatkan dalam proses pembelajaran anak usia dini agar kualitas pendidikan lebih baik lagi.

Dari hasil observasi yang dilakukan, Guru telah mampu untuk mengajar sesuai dengan apa yang telah ditulis dan direncanakan dalam RPPH. Tema-tema yang ditentukan oleh lembaga adalah tema-tema yang dekat dengan dunia anak. Guru mengaplikasikan rencana pembelajaran harian yang telah disusun dalam proses pembelajaran. Walaupun terkadang dalam pelaksanaannya masih ada kegiatan yang telah dirancang tetapi tidak dilaksanakan. Hal ini disebabkan oleh kehadiran peserta didik yang tidak menentu, serta pembelajaran yang dilaksanakan molor dari jam yang telah ditentukan. Hal lain yang terjadi adalah para guru dibeberapa lembaga PAUD membuat perencanaan pembelajaran bukan pada saat sebelum kegiatan belajar berlangsung namun, dibuat setelah kegiatan belajar dilakukan.

Masalah lain yang masih ditemukan juga adalah, dalam mengorganisasikan kegiatan pengembangan, masih terdapat banyak guru yang kurang kreatif menyediakan mediamedia lain yang merupakan hasil karya guru yang dapat digunakan dalam proses pembelajaran. Media yang dipakai hanya fotocopy gambar, dan guru yang memaksakan pembelajaran kepada anak agar anak memiliki semua kompetensi yang ada. Kegiatan pengembangan yang mendidik di luar kelas kurang didukung karena ketersediaan fasilitas bermain serta lingkungan main yang kondusif. Dalam proses belajar, guru lebih memperhatikan kegiatan calistung anak, dimana anak dipaksa untuk mengetahui serta menghafal huruf atapun angka dengan menggunakan metode yang tidak menyenangkan bagi anak.

Disamping beberapa kendala yang disampaikan di atas, terdapat lembaga PAUD yang telah melaksanakan kegiatan belajar sesuai dengan perencanaan yang telah dibuat. Beberapa lembaga PAUD menggunakan model pembelajaran sentra dalam kegiatan belajar. Dalam model pembelajaran sentra guru berperan aktif dalam pembelajaran. Dari hasil observasi yang dilakukan, saat pembelajaran berlangsung guru berkeliling untuk mengecek satu persatu pekerjaan anak. Jadwal untuk penggunaan sentra berbeda-beda setiap harinya. Sedangkan untuk media pembelajaran yang digunakan, guru telah merancang media sesuai dengan tema pembelajaran yang dibahas serta sesuai dengan tujuan pembelajaran. Setiap guru sebisa mungkin membuat dan merancang alat peraga yang menarik bagi anak. Hal ini dilakukan agar pembelajaran tidak monoton. Guru sebelumnya telah membuat rencana pembelajaran harian satu hari sebelum pembelajaran berlangsung. 


\section{Kemampuan guru dalam pelaksanaan pembelajaran}

Dijelaskan oleh Suhana bahwa dengan menguasai materi pembelajaran, guru dapat memilih, menetapkan dan mengembangkan alternatif strategi dari berbagai sumber belajar yang mendukung pembentukan standar kompetensi dan kompetensi dasar (SKKD).(Suhana Cucu, 2014) Penguasaan materi bidang studi merupakan kompetensi pertama yang harus dimiliki guru PAUD sebagai dasar untuk melaksanakan program pembelajaran yang lebih bermakna. Bahan bidang studi terdiri atas pokok- pokok bahasan atau materi-materi pelajaran yang membahas isi bidang pengetahuan yang akan dipelajari dan disajikan setiap kali tatap muka di kelas. Pelaksanaan pembelajaran adalah implementasi dari perencaan pembelajaran yang telah dibuat guru. Artinya dalam pelaksanaan pembelajaran harus sesuai dengan perencanaan pembelajaran yang telah dibuat. Kegiatan pembelajaran meliputi kegiatan pendahuluan, kegiatan inti dan kegiatan penutup. Selain itu, guru juga harus mampu mengembangkan pembelajaran, hal ini sejalan dengan pendapat Zahroh yang menyatakan bahwa pembelajaran kreatif adalah pembelajaran yang dilakukan oleh guru dengan menciptakan kegiatan belajar yang beragam dengan memerhatikan kemampuan dari setiap peserta didik, sehingga mampu memenuhi berbagai tingkat kemampuan peserta didik.(Zahroh, 2015) Pembelajaran disini perlu dilakukan secara teratur artinya guru harus memulai pembelajaran dengan kegiatan pendahuluan terlebih dahulu, kemudian dilanjutkan pada kegiatan inti dan diakhiri dengan kegiatan penutup. Hal yang pertama kali dilakukan oleh guru disini adalah merencanakan segala hal yang akan dilakukan, media, strategi serta metode apa yang akan digunakan. Perencaan pembelajaran ini akan menjadi acuan bagi guru dalam melaksanakan pembelajaran yang terarah.

Agar terlaksananya proses belajar mengajar yang baik tentu adanya metode yang cocok diberikan kepada anak. sehingga proses belajar mengajar terlaksana dengan baik. Sebagaimana yang di ungkapkan oleh Moeslichatoen dalam penelitian Roza, metode merupakan alat untuk mencapai tujuan kegiatan. Sebagai alat untuk mencapai tujuan tidak selamanya berfungsi secara memadai. (Roza, 2012) Oleh karena itu, dalam pemilihan suatu metode yang akan di pergunakan dalam program kegiatan anak di Taman Kanak-kanak guru perlu mempunyai alasan yang kuat dan faktor-faktor yang mendukung pemilihan metode tersebut. Metode pembelajaran untuk anak Taman Kanak-kanak hendaknya menentang dan menyenangkan, melibatkan unsure bermain, bergerak, bernyanyi dan belajar.

Dari hasil observasi dan wawancara yang dilakukan, masih banyak lembaga PAUD yang tidak mengikuti alur perencanaan pembelajaran yang telah dibuat. Terdapat beberapa kegiatan tambahan yang diajarkan guru dilakukan dalam proses pembelajaran walau tidak terdapat dalam perenanaan yang telah dibuat. Kemampuan guru dalam mengaplikasikan RPPH dalam proses pembelajaran tidak terlalu jelas, dimana apa yang diajarkan tidak sesuai dengan apa yang telah direncanakan. Terkadang ada kegiatan main yang telah direncanakan namun tidak dilaksanakan. Kemampuan guru dalam menjabarkan tema ke sub tema tidak terlalu jelas dalam artian guru tidak menguasai tema yang akan diajarkan. Rencana pembelajaran dibuat hanya untuk memenuhi syarat administrasi Guru telah mampu mengkondisikan anak agar mengikuti kegiatan belajar. Namun, Media yang digunakan guru tidak bervariasi dimana guru hanya menggunakan media fotocopy gambar yang diambil dari buku ajar. Media yang digunakan bukan hasil karya guru. Media yang digunakan tidak sesuai dengan tema serta tujuan yang akan dicapai.

\section{Kemampuan guru dalam mengevaluasi pembelajaran}

Disetiap akhir kegiatan belajar, guru wajib untuk melakukan evaluasi. Evaluasi merupakan proses sistematis untuk menentukan nilai berdasarkan kriteria tertentu melalui penilaian.(Jihad, 2013) Bentuk penilaian untuk anak usia dini bias dilakukan melalui hasil kerja anak, catatan anekdot serta ceklis penilaian perkembangan anak. Evaluasi yang dilakukan bias berupa penilaian saat pembelajaran berlangsung ataupun saat anak berada 
diluar ruang kelas untuk melakukan aktifitas fisik lainnya. Evaluasi merupakan bagian dari kurikulum pendidikan, adanya evaluasi guna mengetahui tujuan dari pendidikan yang sudah direncanakan apakah kegiatan belajar mengajar sudah sesuai atau belum. Sedangkan dalam pelaksanaannya yang melakukan evaluasi adalah seorang pendidik. Evaluasi ini dilakukan untuk menentukan kesesuaian Antara hasil yang ingin dicapai dengan tujuan yang ingin dicapai. Penilaian ini akan menjadi tolak ukur kemampuan anak. (Junanto \& Kusna, 2018)

Dari hasil wawancara yang dilakukan dengan para guru, semua guru memberikan jawaban yang sama, yakni penilaian harus dilakukan selama anak berada dilingkungan sekolah serta menggunakan bentuk penilaian yang telah disebutkan diatas. Namun, hal ini berbanding terbalik dengan hasil observasi yang dilakukan peneliti. Masih banyak guru PAUD yang tidak melakukan penilaian yang continue dan berkesinambungan. Dalam artian, para guru hanya mencatat perkembangan tertentu pada anak yang meliputi: perkembangan kognitif, Bahasa dan seni anak. Sedangkan beberapa bentuk perkembangan lainnya yang dapat diperoleh dari hasil aktifias anak diluar ruangan tidak dicatat oleh guru. Beberapa perkembangan yang tidak mendapat perhatian khusus dari guru adalah: perkembangan moral dan social anak, yang dapat dilihat saat anak berada bersama dengan temannya atau saat anak melakukan aktifitas fisik lainnya.

Dari hasil dokumentasi yang dilakukan peneliti, masih banyak sekolah yang tidak menggunakan bentuk penilaian yang variatif dalam menilai perkembangan anak. Lembaga PAUD yang ada hanya menggunakan satu bentuk penilaian yang digunakan. Bentuk penilaian yang banyak dipakai oleh guru PAUD di Kabupaten Manggarai adalah bentuk penilaian portofolio anak. Bentuk penilaian portofolio ini hanya akan memberikan gambaran terhadap beberapa aspek perkembangan saja (Bahasa, kognitif, dan seni). Untuk perkembangan lainnya, bisa dikatakan guru hanya mengandalkan ingatan saja.

\section{SIMPULAN}

Masih banyak guru PAUD yang belum berkualifikasi S1 PAUD atau belum memiliki pemahaman tentang PAUD, Kegiatan main yang disedikan oleh guru tidak mampu untuk mengembangkan aspek perkembangan secara optimal, guru belum mampu mengaplikasikan perencanaan yang telah dibuat dalam kegiatan pembelajaran secara maksimal. Hal lain yang ditemukan adalah dalam mengorganisasikan kegiatan pengembangan, masih terdapat guru yang kurang kreatif menyediakan media-media lain yang merupakan hasil karya guru yang dapat digunakan dalam proses pembelajaran. Media yang dipakai hanya fotocopy gambar. Kegiatan pengembangan yang mendidik di luar kelas kurang didukung karena ketersediaan fasilitas bermain serta lingkungan main yang kondusif. Dalam proses belajar, guru lebih memperhatikan kegiatan calistung anak, dimana anak dipaksa untuk mengetahui serta menghafal huruf atapun angka dengan menggunakan metode yang tidak menyenangkan bagi anak. Terkait penilaian yang digunakan; masih banyak lembaga yang tidak menggunakan bentuk penilaian yang variatif dalam menilai perkembangan anak.

\section{UCAPAN TERIMAKASIH}

Terima kasih yang berlimpah disampaikan kepada lembaga PAUD yang telah menjadi tempat penelitian yang dengan ikhlas dan hati terbuka menerima untuk memberikan informasi terkait penelitian. Terima kasih pula disampaikan kepada pihak lembaga UNIKA Santu Paulus Ruteng yang telah memberikan dukungan dan kesempatan untuk dapat melaksanakan penelitian dengan baik. 


\section{DAFTAR PUSTAKA}

Fransiskus De omes, Stephanus Turibius Rahmat, B. P. Evaluasi Penyelenggaraan Kelompok Bermain dan Taman Kanak-kanak di Kabupaten Manggarai Berdasarkan Norma, Standar, Prosedur, dan Kriteria Penyelenggaraan Menurut Ditjen PAUD. , (2017).

Habibullah, A. (2012). Kompetensi Pedagogik Guru. Edukasi: Jurnal Penelitian Pendidikan Agama Dan Keagamaan, 10(3). https://doi.org/10.32729/edukasi.v10i3.169

Jejen, M. (2012). Peningkatan Kompetensi Guru Melalui Pelatihan dan Sumber Belajar Teori dan Praktik. Jakarta: Kencana.

Jihad, A. dan H. A. (2013). Evaluasi Pembelajaran. Jogyakarta: Multi Presindo.

Junanto, S., \& Kusna, N. A. A. (2018). Evaluasi Program Pembelajaran di PAUD Inklusi dengan Model Context, Input, Process, and Product (CIPP). INKLUSI. https:// doi.org/10.14421/ijds.050202

Majid, A. (2018). Perencanaan pembelajaran. Bandung: Rosdakarya.

Marienda, W., Zainuddin, M., \& Hidayat, E. N. (2015). Kompetensi dan Profesionalisme Guru Pendidikan Anak Usia Dini. Prosiding Penelitian Dan Pengabdian Kepada Masyarakat. https://doi.org/10.24198/jppm.v2i2.13271

Muhamad, F. (2012). Desain Pembelajaran PAUD, tinjauan teoritik dan Praktik. Jogyakarta: ARRUZZ MADIA.

Nurhamida, I. (2018). Problematika Kompetensi Pedagogik Guru Terhadap Karakteristik Peserta Didik. Jurnal Teori Dan Praksis Pembelajaran IPS, 3(1), 27-38. https:// doi.org/10.17977/um022v3i12018p027

Rifma, R. (2013). Problematika Kompetensi Pedagogik Guru Sekolah Dasar. Pedagogi: Jurnal Ilmu Pendidikan, 13(1), 10-17.

Roza, M. M. (2012). Pelaksanaan Pembelajaran Sains Anak Taman Kanak-Kanak Aisyiyah Bustanul Athfal 29 Padang. Pesona Paud.

Suhana Cucu. (2014). Konsep Strategi Pembelajaran (4th ed.). Bandung: Refika Aditama.

Syaiful, B. D. (2005). Guru dan Anak Didik Interaksi Edukatif. Jakarta: PT Rineka Cipta.

Wahyuni, R., \& Berliani, T. (2018). Pelaksanaan Kompetensi Pedagogik Guru di Sekolah Dasar. Sekolah Dasar: Kajian Teori Dan Praktik Pendidikan, 27(2), 108-115. https:// doi.org/10.17977/um009v27i22018p108

Wulandari, D. (2012). Pengaruh Kompetensi Pedagogik dan Kompetensi Profesional Guru terhadap Economic Literacy melalui Prestasi Belajar Siswa Kelas XII IPS di SMA Kota Malang. Jurnal Pendidikan Humaniora.

Zahroh, A. (2015). Membangun Kualitas Pembelajaran Melalui Dimensi Profesionalisme Guru (5th ed.). Bandung: Yrama Widya. 